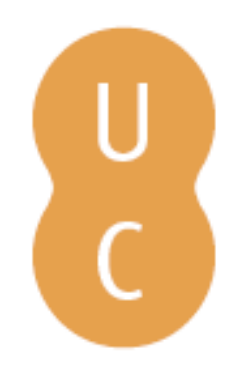

\title{
pompalina
}

\section{Garrett e as mulheres: deleites e delitos}

Autor(es): $\quad$ Machado, Fernando Augusto

Publicado por: Imprensa da Universidade de Coimbra

URL

persistente: $\quad$ URI:http://hdl.handle.net/10316.2/38686

DOI: $\quad$ DOI:http://dx.doi.org/10.14195/978-989-26-1164-8_9

Accessed : $\quad$ 26-Apr-2023 11:45:43

A navegação consulta e descarregamento dos títulos inseridos nas Bibliotecas Digitais UC Digitalis, UC Pombalina e UC Impactum, pressupõem a aceitação plena e sem reservas dos Termos e Condições de Uso destas Bibliotecas Digitais, disponíveis em https://digitalis.uc.pt/pt-pt/termos.

Conforme exposto nos referidos Termos e Condições de Uso, o descarregamento de títulos de acesso restrito requer uma licença válida de autorização devendo o utilizador aceder ao(s) documento(s) a partir de um endereço de IP da instituição detentora da supramencionada licença.

Ao utilizador é apenas permitido o descarregamento para uso pessoal, pelo que o emprego do(s) título(s) descarregado(s) para outro fim, designadamente comercial, carece de autorização do respetivo autor ou editor da obra.

Na medida em que todas as obras da UC Digitalis se encontram protegidas pelo Código do Direito de Autor e Direitos Conexos e demais legislação aplicável, toda a cópia, parcial ou total, deste documento, nos casos em que é legalmente admitida, deverá conter ou fazer-se acompanhar por este aviso.

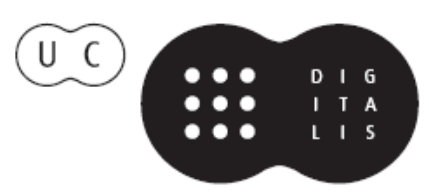


Fernando Augusto Machado

Universidade do Minho

\section{GARRETT E AS MULHERES: DELEITES E DELITOS}

\section{Uma vida de deleites com laivos de mácula}

Com data de 1821 e vinte e dois anos de idade, o jovem poeta fazia já valer as suas experiências de sucessos e desditas de amor no consolo a um amigo sofredor de recentes maleitas de coração:

Consola-te comigo, meu Sarmento, Consola-te comigo,

Também eu fui patau, também as Mársias,

As Análias, Armias,

Me deram que fazer, me atarantaram

Nos meus tempos de amante.

Também de uns olhos já pendeu meu fado, ${ }^{1}$

Muito mais tarde, nas Folhas Caídas (1853), em contexto da sua última e maior paixão, escrevia o eterno amante:

Este inferno de amar - como eu amo!

Quem mo pôs aqui n'alma... quem foi?

Esta chama que alenta e consome,

1 Almeida Garrett [A. G.], Obras de... Porto, Lello \& Irmão - Editores, 1966, vol. I, p. 1582 O poema intitula-se "Consolações a um namorado" e está inserto na Lírica de João Mínimo (1829). 
Que é vida - e que a vida destrói -

Como é que se veio a atear,

Quando - ai quando se há-de ela apagar? ${ }^{2}$

Seria quimérico tentar analisar ou compreender a vida e a obra de Almeida Garrett (1799-1854) sem este núcleo estruturante das mulheres. Assim o entendeu, embora nem sempre de forma pacífica e quase sempre com lamúrias de reserva moral, como teremos oportunidades de ver, o seu insubstituível e meticuloso biógrafo Gomes de Amorim, quando acrescentou à trindade santa - Deus, Liberdade e Pátria - outros três vetores que dominaram e deram sentido à vida e escrita do seu biografado: as letras, a politica e as mulheres ${ }^{3}$, mulheres que haveria de considerar, também, "o escolho da sua vida e a perene tentação da sua alma" ${ }^{\prime 4}$. Aliás, aquela realidade foi, também, convicta e profusamente assumida pelo próprio autor das Viagens na Minha Terra, obra onde ensaia "teorização" do facto com argumentos de convicção sua e testemunhos de outros, embora em torno de teses de índole diversa. Diz ele, abrindo o capítulo XI do escrito: "Este é o único privilégio dos poetas: que até morrer podem estar namorados"; e um pouco à frente, recorrendo a um paradigma ao sabor do tempo, ditava: "O coração humano é como o estômago humano, não pode estar vazio, precisa de alimento sempre" . Pois bem, Garrett gozou com denodo esse privilégio único dos poetas e deu cumprimento ao ditame paradigmático, tendo tido sempre o seu coração alimento farto, eventualmente em sobreposse, várias vezes em sobreposição, mas nunca esgotando ou alheando créditos da sua capacidade de amar. Ele tinha "poderes de mais no coração", tinha mais sentimento que imaginação, não conseguiu graduar a dose de anfião, como Goethe, nem seguir a prevalência da imaginação sobre o sentimento, como Homero, Sófocles ou Voltaire. Seguiu Byron, Schiller, Camões e Tasso ${ }^{7}$, e isso o havia de matar tão cedo, como a

Ib., vol. II, p. 177.

3 Francisco Gomes de Amorim, Garrett, Memórias Biográficas, Lisboa, Imprensa Nacional, vol. III [I-III], 1884 [1881 (I) - e 1884 (II e III], p. 37.

4 Ib., vol. II, p. 320.

5 A. G., Viagens na Minha Terra, Edição Crítica das Obras de..., Edição de Ofélia Paiva Monteiro. Lisboa, Imprensa Nacional-Casa da Moeda, 2010, pp. 163-165.

6 Ib., p. 421.

7 Ib., 317-318. 
estes sucedeu. Ele previu ${ }^{8}$, mas não conseguiu evitar; Gomes de Amorim havia de confirmar esta incapacidade e esta previsão: "Tal foi a sua [morte]. Tão bem se descreveu, que até a profetizou, nove anos antes! O coração matou-o. Porque, é ele que o diz, que nos discursos políticos o confessa, tinha coração de mais" .

Pois bem, nasceu muito cedo no que seria, também, poeta da liberdade, este fogo de amores e paixão que o tempo foi ateando e que, também cedo, lhe delineou caminhos de existência e sentidos de vida. É sabido o ambiente de forte religiosidade que o rodeou e a circunstância de vários membros da família envergarem hábito eclesiástico, alguns com pergaminho. Foi, por isso, natural projetarem destino ao menino de tenra idade, confirmado nos Açores ao adolescente que também já era poeta: havia de ser padre, enquanto não fosse bispo ou até cardeal, como a fulgurante inteligência, aliada aos créditos familiares do ramo, a todos fazia prever. Por isso, o tio bispo Frei Alexandre da Sagrada Família providenciou em tempo devido para que o sobrinho recebesse ordens menores para mais tarde professar. Vestiu nessa condição trajes batinais e chegou mesmo a ensaiar o púlpito em dia de festa na Graciosa, pregando sermão à revelia de outro tio a quem fora visitar nessa ilha. Ora, reza a crónica mais oficial que, algum tempo depois, em momento de despedida do irmão Alexandre que zarpava para o continente a exercer profissão, o jovem problematizou criticamente o seu destino devido a saudades, sentidas naquela hora, dos locais nortenhos do continente onde vivera a infância, e à angústia emergente do acanhado espaço insular que se lhe afigurava para vida futura. Teria deixado, então, à sombra destes pressupostos, ecoar "o cântico da natureza na primavera humana", como confidenciou um dia a Gomes de Amorim ${ }^{10}$, deliberando perentório: "Padre! Nunca!", resolvendo, isso sim, ir para Coimbra estudar, evitando assim o labéu de um mais que provável futuro sacerdote prevaricador, conforme lhe ditava a íntima convicção. Só que este "cântico da natureza na primavera humana" havia de ser depois melhor figurado por informação mais tardia, e que o biógrafo referido remeteu para uma nota de fim de página: afinal, amores juvenis do poeta na Terceira terão sido não só causa

\footnotetext{
8 Ib., 364.

9 Francisco Gomes de Amorim, Garrett, Memórias..., op. cit., Vol. III, p. 84.

10 Ib., vol. I, p. 103.
} 
primordial para a obnubilação da vocação sacerdotal, como terão facilitado, para contento do jovem, a resignação dos pais e restante família, para deixá-lo rumar à universidade, pois não viam com bons olhos tais devaneios mulherengos em tão tenra idade. Este quadro receberá mais tarde confirmação no seu Chaveco Liberal, em 1829, onde o então exilado escreveu sobre si: “...assim mestre calafate como aqui me vêem, fui estudante no meu tempo, e maldita seja a moça que me andou co'a cabeça à roda e foi causadora de eu não ter hoje as orde's com'o nosso capelão..." ${ }^{\prime 1}$.

Pode ter sido este o primeiro altar da sua religião dos olhos pretos $^{12}$, religião que não desmereceria pelos tempos futuros os de outras cores. À dona terá deixado e ele terá também trazido negro o coração. Não por muito tempo, no caso dele, como tudo o indica. Na vida de estudante na cidade universitária foi-lhe florescendo e dando frutos a veia poética e dramática, ao mesmo tempo que colhia e vivenciava amores diversificados, cruzando polos em dialéctica imparável: as mulheres inspiravam, a poesia surgia e atraía, a vivência colhia e de novo inspirava, repetindo-se o processo, sempre... No "A quem ler" (1853) que introduz as Fábulas e Contos, pintará com realismo este novo quadro de vida no continente, no contexto de caraterização da sua Lírica de João Mínimo. Nesta obra, dizia o escritor em ano prévio à sua morte, "está a infância poética, toda a vida juvenil do homem de letras, do artista, do patriota sincero e inocente, do entusiasta da Liberdade [...]". E mais à frente continuava:

Fala de amor o poeta... Sim, fala, e há Délias, e há Lílias, e háflores e há estrelas, e há beijos e há suspiros, e há todo esse estado-maior e menor de um exército de paixões que sai a conquistar o mundo no princípio da vida de um rapaz cheio de alma, de fogo, de exuberante energia e veemência de sangue ${ }^{13}$.

O quadro assim descrito e datado da era juvenil é aplicável a toda a vida do sempre enamorado e apaixonado poeta. Herculano, que pacientemente chegou a fazer de pau-de-cabeleira em encontros do amigo com a sua explosiva paixão,

\footnotetext{
11 Ib., p. 109.

12 Outros de quinze anos havia de deixar anos mais tarde, em S. Miguel, na hora de embarque para o Porto, para combate dos exércitos miguelistas (ib., 563).

13 A. G., Obras de... op. cit, Vol. I, 1661.
} 
a Viscondessa da Luz, registaria, em carta de 1867 a Gomes de Amorim, este facto e o espanto pela viçosa força inalterável de coração do eterno amante: "Bem sabe que o Garrett morreu (em certas relações) com os mesmos vinte e cinco anos que tinha trinta anos antes" ${ }^{\prime 4}$. E de facto podemos interrogar-nos sobre o que separa aquela paixão relâmpago que o acometeu naquela noite de setembro de 1821, tinha vinte e dois anos, quando representou o seu Catão no Bairro Alto de Lisboa e deparou, entre a chuva de ramos e lenços beijados e lacrimosos de muitas admiradoras ilustres e rendidas que o disputavam, com a sereia de treze anos cuja beleza e formas virginais o sideraram e que se tornaria, um ano depois, sua mulher... e aqueloutra que, pecaminosamente, viveu na última fase da vida com a amante Rosa Montúfar Barreiros, a também bela andaluza gaditana, casada com o oficial do exército português Joaquim António Barreiros? A primeira, para além do fogo apaixonado assente na fogosidade da vida juvenil, concedeu-lhe o único estatuto de bem casado que experimentou, concedeu-lhe companhia e amor quanto baste nos difíceis tempos de perseguido, exilado e empobrecido, mas acabou por transformar-se em "estrela funesta" geradora de infelicidade que nem sequer a separação conseguiu erradicar; a segunda fê-lo renascer e permitiu-lhe retomar todas as fantasias do tempo juvenil e torná-las reais com intensidade sem par e paixão quase sem limites, como se pode constatar na letra e implícitos das poucas mas cálidas cartas que o poeta lhe escreveu e que sobraram de desastrada destruição ${ }^{15}$, e sobretudo deu-lhe ocasião de criar os sublimes versos que consagrou Ignoto Deo, reunidos nas Folhas Caídas (1853) e que constituem "talvez o mais assombroso sucesso que em Portugal se tem dado com um livro", como augura Amorim ${ }^{16}$. Com efeito, esta obra viu a primeira edição esgotada entre Abril e Maio, tendo sorte paralela a segunda, fazendo lembrar sucessos que no século anterior tinha tido a apaixonante Julie ou la Nouvelle Heloïse, Lettres de Deux Amants, de Rousseau, que conhecera 72 edições

\footnotetext{
14 Francisco Gomes de Amorim, Garrett, Memórias.., op. cit., vol. III, p. 225.

15 Em 2004, saiu uma edição brasileira (Rio de Janeiro, 7Letras) das Cartas de Amorà Viscondessa da Luz, com introdução, organização, fixação de texto e notas de Sérgio Nazar David. Em 1954 saíra a edição com o mesmo título (Lisboa, Empresa Nacional de Publicidade), organizada por José Bruno Carreiro.

16 Op. cit., vol. III, p. 397.
} 
nos primeiros 39 anos de existência ${ }^{17}$, sendo, também aqui, as mulheres as principais responsáveis do sucesso.

No largo intervalo que separa estas duas tão fortes mas tão distintas paixões, sobram outras focadas em Délias, Lílias e Análias, em Lídias, Luísas, Lucindas e Adelaides, em Joaninhas, Lauras, Júlias e Georginas, não faltando sequer ocasião, supostamente sublimada, para induzir devaneios em "devotas", "formosas" e "açucaradas" freiras, como as do convento de Santa Clara de Vila do Conde, as mesmas, aliás, que posteriormente cantaram Te Deum em protecção da esquadra miguelista que quiseram brindar com refrescos, solicitando presença viva de oficiais para com elas tomarem chá...

Em junho de 1836, Garrett separou-se da mulher Luísa Midosi que o "desonrara". Quanto pesou esta "desonra" em quem tanto fruíra com outras! Mas entretanto, conheceu por esse tempo de tormentoso sofrimento a doce e fiel jovem de 18 anos, Adelaide Pastor, que se lhe dedicou, o consolou, lhe deu paz e amou sem condições nem sacramento. Deu-lhe também três filhos, mas destes restou apenas Maria Adelaide, a única que o havia de ver morrer. Ele amou Pastor, e foi esse amor calmo que o fez guardar lugar de morte ao lado dela e dos outros dois filhos falecidos, no cemitério de S. João: "Espero e desejo que minha filha saiba, se eu não viver até eu lho poder dizer, que a minha vontade inalterável e o meu ardente desejo é que as minhas cinzas ali sejam postas ao pé das de meus filhos e da minha Adelaide"18. Palavras sinceras e ternas! Contudo, na vida comum que ambos tiveram, não conseguiu abster-se de outros deleites. E tendo ainda a alma de luto e planeando aqueles destinos tumulares, já se lhe perfilava, sem atender sequer à inquietação, que de facto tinha, da responsabilidade de ser pai e mãe da filha ainda bebé que ficara, o regresso ao dogma dos olhos pretos através de uma enigmática Ela, a quem haveria de conceder duplo privilégio supremo: o de ser, simultaneamente, primeiro e último, ou seja, único amor da sua vida, aquele a quem as suas Asas Brancas também se renderam, pesadas, trocando o próprio céu e as estrelas por Ela:

17 Cf. Fernando Augusto Machado, Rousseau em Portugal, da Clandestinidade Setecentista à Legalidade Vintista (Porto, Campo das Letras, 2000), p. 183.

18 Francisco Gomes de Amorim, Garrett, Memórias..., op. cit., vol. III, pp. 71-72.. 
O meu amor primeiro,

Único, derradeiro,

Achei-o pois: é Ela. - Ela um mistério,

Um sonbo - um véu caído

Sobre um simbolo! Um mito...

Mas é Ela... Ob! É ela! Eterno império

Lhe foi, desde o princípio concedido

Em meu ser imortal. Sou, fui... escrito

Está que sou, que fui, que era já dela,

Desde que há ser em mim. ${ }^{19}$

Aqui está Ignoto Deo antecipado em dez anos. O bom Gomes de Amorim ainda pensou que se tratasse de uma homenagem à sua fiel Adelaide, mas depressa concluiu o contrário, pois não podiam tais versos e os restantes do poema, pela paixão ardente que transportavam, ser inspirados na devotada companheira de casa e mãe dos filhos de ambos! Desta forma, Garrett adulterava quase toda a vida vivida: a do período de bem casado, com adultério de formalidade legal; a do período restante, relativamente a muitos amores, incluindo o da tão devotada Adelaide Pastor, com "adultério" moral.

Oh! os poetas!... Quem ousará ler o livro incompreensível, que Deus inscreve nessas almas privilegiadas, sondar esses misteriosos abismos sem fundo?! Os seus corações vivem de ternura, como as plantas de ar e de luz. A poesia é a sua Dejanira, envolvendo-os eternamente na túnica funesta, que lhes abrasa o sangue, e thes devora a vida com a sede insaciável do amor. Mas poderia a abelha compor o mel delicioso com o suco de uma flor única? [...]

Deixemo-los, pois, mariposas sublimes, remontar-se aos astros, em busca da inspiração divina [...].

Que importa o sacrificio, se dos seios das vítimas nascem os imortais poemas, os cantos eternos, que resgatam todas as faltas, e que honram a humanidade ${ }^{20}$

19 A. G., Obras de... op. cit., vol. II, p. 135. Este poema "Ela", integrou-O ainda nas Flores sem Fruto. Aparece com datação incompleta de $184 \ldots$, mas a data de saída da obra é 1843, pelo que o poema será desse ou de ano anterior. Ora, Adelaide Pastor morreu em 26 de julho de $1841 \ldots$

20 Francisco Gomes de Amorim, Garrett, Memórias ..., op. cit., vol. II, p. 714. 
Assim se exprime, no fim do segundo volume, o moralista autor das Memórias. São palavras ao arrepio de desejos e lamentos que noutras ocasiões expressou atinentes ao sentido e orientação de vida do poeta relativamente à cegueira com as mulheres com quem tanto tempo de vida perdera com manifestos e vários prejuízos, nomeadamente para a criação literária. Desta vez, contudo, não se mostrou apenas benevolente para tais descaminhos, encarou-os até positivamente enquanto condição de criação poética. Garrett assim pensava e assim se exprimiu várias vezes sobre a questão. Mesmo assim, não deixaria de se questionar sobre a crueza e nefastos efeitos da sua porfiada volubilidade que semeava feridas sentimentais nos corações das suas amadas. Aliás, ele próprio sangrou algumas vezes deste mal, como foi no caso da sua mais arrebatada paixão com a Viscondessa da Luz. Provam-no em demasia as referidas cartas que lhe dirige, onde perpassam repetidos queixumes a contenções cautelares da amante, ciúmes quase doentios, insatisfação por encontros falhados ou curtos, inconformismo e desgosto por ter de a compartilhar. Por isso, lastima as suas condutas e incrimina-se até, por vezes. Só que estas desobrigas não conseguem esconder sinais de evidentes delitos de género. Sigamos a dupla fórmula das Viagens através do importante espelho autobiográfico de Carlos. Por um lado, Joaninha recebe confissões, em ecos variados, que acoitam reconhecimentos pessoais de culpabilidade: “...perde-se-me esta cabeça nos desvarios do coração. Errei com ele, perdeu-me ele... Oh! bem sei que estou perdido" ${ }^{21}$. Situa a causa em si próprio, repetindo em diversas ocasiões o mote: "Eu estou perdido. E sem remédio, Joana, porque a minha natureza é incorrigível. Tenho energia de mais..."22; um pouco à frente continua: "...amei-te com um coração que já não era meu; aceitei o teu amor sem o merecer, sem o poder possuir, traí quando te amava, menti quando to disse, menti-te a ti, menti-me a mim, e não guardei verdade a ninguém”; e em rebate de culpa assumida, declara:

Ob! eu sou um monstro, um aleijão moral deveras, ou não sei o que sou" [...]. Sabia que era monstro, não tinha examinado por partes toda a hediondez das feições que me reconbeço agora.

Tenho espanto e borror de mim mesmo ${ }^{23}$.

\footnotetext{
${ }^{21}$ A. G., Viagens na minha Terra... op. cit., p. 421.

$22 \mathrm{Ib}$.

23 Ib., 441-442.
} 
Mas por outro lado, esta responsabilização individual, escudada ou não em exigências de criação poética, torna-se, em algumas ocasiões, imperativo ou pelo menos vocação de natureza, um ou outra ditados pela natureza do género, com carácter de universalidade, portanto incontornáveis. Cruzam-se e fundam-se, até, numa responsabilização social que ele torna, também, universal e incontornável, habilitando o chamado "sexo forte" a poder ser desigual, fazendo-o usufruir de claras vantagens físicas, sociais, morais, e até legais. Atente-se:

Tu não compreendes isto, Joaninha, não me intendes decerto; e é difícil. És mulher, e as mulheres não intendem os homens. Sempre o entrevi, hoje sei-o perfeitamente. A mulher não pode nem deve compreender o homem. Triste da que chega a sabê-lo!... ${ }^{24}$

E para a frente clarificará:

"Se todos os homens serão assim?

Talvez, e que o não digam" ${ }^{25}$.

Desta forma, Garrett, através de Carlos, assume a diferença de natureza dos dois interlocutores: Joaninha permanece limpa segundo os ditames da natureza, como, aliás, as três irmãs que amou em sobreposição, Laura, Júlia e Georgina que viviam no "Éden da inocência"; Carlos tornara-se homem de máscaras formatado pela sociedade existente e a ela apropriado. Colocava, assim, cada género a viver a sua "naturalidade", e aceitar isto era aceitar a desigualdade, pelas implicações que daí decorriam. Ela, a mulher, teria de ter, necessariamente, uma vida singela, recatada, sem doutorices, num mundo fechado ao social e ao civilizacional existentes. Era esse, aliás, o desejo de Carlos, de Garrett, para seus contento e proveito, claro. Se quer o regresso, seu e dos do seu sexo, à inocência natural que deseja para a prima e para as outras mulheres? Não parece, a medir pelo fim da longa carta:

\footnotetext{
24 Ib., p. 422.

25 Ib., p. 441.
} 
...eu que farei?

Creio que me vou fazer homem político, falar muito na pátria com que me não importa, ralhar dos ministros que não sei quem são, palrar dos meus serviços que nunca fiz por vontade; e quem sabe?... talvez darei por fim em agiota, que é a única vida de emoções para quem já não pode ter outras ${ }^{26}$.

Este é o ambiente da cidade conspurcada. Garrett chama Rousseau neste e noutros confrontos entre natureza e sociedade, entre autenticidade e máscara, entre frugalidade e agiotagem, entre simplicidade e doutorice. São polos recorrentes que seguem o perfil traçado no capítulo XXIV da obra, onde decalca o início do Émile, do mestre genebrino. Leia-se este:

Tudo está bem ao sair das mãos do Autor das coisas, tudo degenera entre a mão do homem". [...] Ele subverte tudo, desfigura tudo, ama a deformidade, os monstros; não quer nada tal como o fez a natureza, nem o próprio homem ${ }^{27}$.

Depois vai mostrando os contrários e provando como "As boas instituições sociais são as que melhor sabem desnaturar o homem"28, mascarando-o, escravizando-o, sujeitando-o a ferros, tornando-o unidade fracionária, enfim, tornando-o tal como é na sociedade vigente. Leia-se agora o molde do cidadão da Invicta: "Formou Deus o homem, e o pôs num paraíso de delícias; tornou a formá-lo a sociedade, e o pôs num inferno de tolices"29. Depois, como o seu inspirador, vai descrevendo também os contrários para relevar o homem que a sociedade tem contrafeito, apertado e forçado em grades de ferro, esse homem "aleijado como nós o conhecemos", "o animal mais absurdo, o mais disparatado e inconsequente da terra, rei que perdeu a realeza, príncipe deserdado e proscrito, altivo e soberbo do seu estado passado mas baixo, vil e miserável pela desgraça do presente ${ }^{30}$. Mas afinal, é neste segundo mundo de desmerecimento e tolices que situa, com claras vantagens, os privilegiados poetas e civilizados

\footnotetext{
26 Ib., p. 456.

27 J.-J. Rousseau, Émile ou de l'Éducation, Paris, Garnier-Flammarion, 1966, p. 35 (tradução).

28 Ib., p. 39.

29 A. G., Viagens Viagens na minha Terra... op. cit., p. 421.

$30 \quad$ Ib., pp. 279-280.
} 
homens, contra o paraíso de delícias naturais, o éden da inocência em que coloca as mulheres que não só não poderão usufruir das benesses da cidade como nem poderão calcorrear caminhos de produção poética.

Voltaremos mais à frente aos delitos aqui prefigurados.

\section{Um ousado naturalismo sensualista}

Embora exibindo algumas ambiguidades e contradições entre o natural e o social, entre o pensar e o viver, entre os dois polos do género, Garrett abraçou cedo o esplendor do naturalismo na acepção mais pura, herdada do Discurso sobre a origem e fundamentos da desigualdade, do mestre Rousseau. Nunca abandonou esta herança, embora apareça diluída na fase da prevalência da fecunda produção romântica da maturidade. Mais tarde, as Folhas Caídas potenciá-lo-ão de novo, através de um sensualismo sem limites e despreconceituado, "com nova transparência, por alguns acusada de despudor", como assinala Ofélia Monteiro ${ }^{31}$, roçando o realismo, com a alma rendida ao corpo que nada numa sensualidade de feição quase materialista e clamando uma moral naturalista à revelia da religião. Nesta ação de retoma, abençoará o exercício do império dos sentidos e realizará o céu na terra, invertendo valores de uma prática centenária. O destemor intelectual e de vida da irrequieta e fremente juventude renascia aqui.

Não te amo, quero-te: o amar vem d'alma.

E eu n'alma - tenho a calma,

A calma - do jazigo.

Ai! Não te amo, não.

[...]

Ai! Não te amo, não; e só te quero

De um querer bruto e fero

Que o sangue me devora,

Não chega ao coração ${ }^{32}$.

31 Ofélia Paiva Monteiro, "Introdução", in A. G., Viagens na minha Terra... op. cit., p. 18.

32 Do poema "Não te Amo", das Folhas Caídas (A. G., Obras de..., op. cit., vol. II, p. 200). 
Havemos de voltar a este tempo e a esta obra e seus significados. Digamos agora que se este naturalismo sem rebuços colocava o autor de Helena nos caminhos mais avançados, ousados e férteis do iluminismo, com repercussões profundas no seu ideário político, religioso, antropológico e moral, também nele faria radicar alguns delitos pouco esperados neste Alceu da liberdade e do progresso, pelas opções tradicionalistas que dele fez brotar. A questão geral das mulheres situa-se nesta sombra. Percorramos uma breve resenha da formação e das hermenêuticas do culto escritor que nos façam entender esta contraditória dualidade e esta mácula ${ }^{33}$.

Ainda residente com a família nos Açores, Garrett teve oportunidade, logo a partir dos 13 anos, de ter contacto, através de traduções francesas, com os sistemas filosóficos de Locke, Leibniz, Kant e Newton. Sustentava estas investidas portadoras de heterodoxia a recheada e despreconceituada biblioteca do tio bispo. Mas terá sido já no continente, quer por bibliotecas conventuais que os pergaminhos eclesiásticos da família the abriam, quer nas várias sociedades secretas a que pertenceu, quer nas redes de compra e empréstimos que vogavam pelo círculo académico, que ele adquiriu o lastro iluminista, sobretudo pela via do enciclopedismo. Foram estas competências, dificilmente ombreáveis na época, que lhe deram à-vontade suficiente para invocar bases argumentativas de Rousseau, Mably, Volney e Condorcet na prova da sua tese de O Dia Vinte e Quatro de Agosto (1821); que o encorajaram, perante uma parcela do escol intelectual e político do país, na Sociedade Literária Patriótica de Lisboa, a lidar com teorias de Rousseau assentes nos Discurso sobre as Ciências e as Artes e Discurso sobre a desigualdade, e do materialista Helvécio; a chamar à colação, com frequência, Montesquieu, Voltaire, Diderot, Condillac...; enfim, a afirmar que a Revolução de 1820 o encontrara rodeado de enciclopedistas, Voltaires e Rousseaus ${ }^{34}$. Assim era, e assim o mostrou em profusão. Centremo-nos no assunto que nos interessa.

33 Pode ler-se, para mais ampla recolha nesta matéria, Fernando Augusto Machado em: Almeida Garrett e a Introdução do Pensamento Educacional de Rousseau em Portugal (Porto, Edições ASA, 1993), "Introdução" a A. G., Da Educação, Edição Crítica das Obras de..., Lisboa, Imprensa Nacional-Casa da Moeda, 2009 e "Ideário Educacional e Pedagógico de Almeida Garrett, Modernidade e Tradicionalismo", in Colóquio / Letras - No segundo centenário de Almeida Garrett, $n^{\circ}$ 153/154 (julho-dezembro 1999), pp. 87-106.

34 A. G., Obras de... op. cit., vol. II, p. 461. 
Foi sobretudo pela via naturalista que o iluminismo o tocou nos verdes anos da sua juventude. Isto é importante pelo vasto campo que esta corrente abrange quer em termos de princípios, quer de valores, quer de consequências. Novas concepções do mundo, do homem e de Deus advieram e fizeram iniciar a marcha de uma progressiva secularização. Natureza, direito natural, materialismo, mecanicismo, lei, desteologização, religião natural e deísmo, importância do corpo, sensualismo, prazer, felicidade imanente, etc. são termos e conceitos de grande voga. Garrett incorporou-os, por vezes nas suas facetas mais puras tal como vigoravam nas fontes onde os bebeu. Folheemos algumas destas fontes:

Na entrada Loi Naturelle (Morale), a Encyclopédie de Diderot e D’Alembert regista, seguindo padrão claramente rousseauniano teorizado no Émile e pairando na Nouvelle Héloïse: "A lei natural é a ordem eterna e imutável que deve servir de regra às nossas acções”. E à frente: "Que seja máxima para nós incontestável, que os caracteres da virtude estão escritos no fundo das nossas almas [...]. Numa palavra, a lei natural está escrita nos nossos corações em caracteres tão belos, com expressões tão fortes e traços tão luminosos, que não é possível desconhecê-la"35. Assim, moral e virtude deixam de ser vontade de Deus, imperativos da religião e de estar inscritas na Escritura Sagrada e tornam-se imperativo da Natureza inscrito no coração do homem em que corpo e sentidos adquirem destaque para bem-estar e felicidade na imanência. A Natureza une a vida, e o homem aproxima-se do animal e da planta em busca de leis universais. Neste esteio, Voltaire inicia, no seu Dictionnaire Philosophique ${ }^{36}$, o artigo Amour com a célebre frase das Geórgicas de Virgílio, tornada aforismo: Amor omnibus idem (o amor é para todos igual). E prossegue: "Queres ter uma ideia do amor? Vê os pardais do teu jardim; vê os pombos; vê o touro que se leva à novilha; vê esse orgulhoso cavalo que dois criados conduzem à égua que o espera e que desvia a sua cauda para o receber; vê como os seus olhos brilham...”. As diferenças destes animais para o homem serão algumas, mas o paradigma mantém-se, reinando os sentidos geradores de prazer.

35 Encyclopédie ou Dictionnaire Raisonné des Sciences des Arts et des Métiers par une Société de Gens de Lettres, vol. IX. A Neufchastel, Chez Samuel Faulches \& Compagnie, Libraires et Imprimeurs, MDCCLXV.

36 Paris, Garnier-Flammarion,1964. 
Ora, percorram-se algumas criações do poeta em época temporã, e veremos, com abastança, a sintonia. Atemo-nos a dois sonetos que o poeta data de 1817 e 1818 , respetivamente: ${ }^{37}$

Nas froixas, débeis asas da saudade

Esses muros que amor, razão despreza,

Que ergueu do fanatismo a voz trovosa,

Deixa, ó Nice, deixa-os vaidosa

De escutares a voz da Natureza.

Crê no teu coração; não é fraqueza

Fugir dos males para ser ditosa:

Já nos meus braços a ventura ansiosa

Espera, com amor, tua beleza.

Vem, não oiças conselhos fementidos,

Ouve amor, a razão, a liberdade,

E a virtude e o prazer verás unidos. ${ }^{38}$

Farás minha cabal felicidade,

Nem teus votos verás sempre perdidos

"Nas froixas, débeis asas da saudade."

Virtude sem amor não é virtude

Deixa, eu te rogo, deixa Anália minha

Duros preceitos de moral sombria;

Fingiu-os a traidora hipocrisia

Que detrás deles, a zombar, se aninha.

37 A. G., Obras de... op. cit., vol. II, pp. 1716 e 1718.

38 É nosso o sublinhado. 
Leis de tartufos, invenção daninha

Que protege a impostura, e o vício cria

O egoísmo as ditou, funesta harpia

Que as horas de gozar nos amesquinha

A mão da Natureza, a mão sublime
O grão selo forjou na eterna incube
Com que o sinal de falsas thes imprime

O coração mo diz, que não ilude:

Crime sem dor, Anália, não é crime,

"Virtude sem prazer não é virtude.» ${ }^{39}$

A toada segue noutras composições, como naquela em que ensina, em 1820, "Ao Corpo Académico" que:

São leis da Natureza as leis divinas:

Disse-o a Palavra d'Ele,

Diz-no-lo a voz do coração que é sua. ${ }^{40}$

Ou quando, em toada libertina que aprendera com os philosophes e com Bocage, apela, em 1819, às mulheres do Porto, "Rústicas Misses, Ladies sensaboras", para que se libertem e lancem ao Douro os trajos démodés e os biocos negros, "mortalha de invenção fradesca", de forma a poderem ser contempladas as graças que a Natureza lhes outorgou ${ }^{41}$.

Mas a grande plataforma deste naturalismo sensual e deste libertinismo, professado nos verdes anos, foi o poema O Retrato de Venus. Não iremos analisar a obra na globalidade, já muito tratada ${ }^{42}$. Delinearemos um breve apontamento mais projetado para o nosso tema.

39 É nosso o sublinhado.

40 Ib., vol. I, p. 1575.

41 Ib., vol. I, p. 1550, no poema "As Férias", da Lírica.

42 Lembramos como exemplos, o cap. V da obra de Ofélia Monteiro, Almeida Garrett, Experiência e Formação (Coimbra, Centro de Estudos Românicos, 1971) e A Polémica sobre o Retrato de Vénus, org. e com introdução de Maria Antonieta Salgado (Lisboa, Imprensa Nacional-Casa da Moeda, 1983). 
Os desmandos heterodoxos, "heréticos" e impudicos do nosso poeta levaram, como é sabido, autor e obra a tribunal no país já livre, por pressão de exasperados "Católicos Romanos" bem representados pelo atrabiliário frade Agostinho de Macedo. Os nós de acusação tinham que ver, sobretudo, com desvios teológicos e religiosos e com questões morais. Sob a escandalosa égide do corifeu do epicurismo, Lucrécio, e, na peugada do materialista Demócrito, o fogoso Alceu da liberdade e desafiador da Igreja e da moralidade tradicionalista erigiu, à revelia dos dogmas sagrados, a Natureza como mãe do universo, corporizada nos fabulosos deuses Cupido e Vénus; entronizou a razão e os sentidos; colocou a fé nos limites da razão, subalternizando a esta a escritura sagrada e fazendo cair argumentos não racionais ou de mera autoridade. Mas em toda a refega travada, sobressaem, na irritação dos acusadores que escreveram na Gazeta Universal, dita dos Corcundas, as impudícias do seu exacerbado naturalismo e do sensualismo sem limites, provocatórios da moralidade pública.

As acusações encontram, de facto, substância nos versos. Com efeito, o autor naturaliza neles o céu e os deuses, e abençoa nestes o que na tradição cristã e moral católica era o pecado mais hediondo e perseguido: o pecado da carne! Em nome da mãe Natureza, o poeta corporiza os deuses e concede-lhes a experimentação de uma felicidade suprema através dos prazeres do sexo. E fá-lo de forma tão realista e desprezível de recato que descreve, sem pudor, os sinais tão humanos quanto animalescos do gozo, retratando as lânguidas pupilas, o palpitar dos seios voluptuosos, o lascivo aperto dos braços níveos, os olhos em que a luz quase se extingue, a vOz interrompida e soluçada, os derradeiros ais estremecidos dos divinais amantes, e como não bastasse, tudo em pecaminosa situação de celeste adultério.

Esta audácia irreverente estava já consignada em poema de 1820 que permaneceu "ineditamente centenário" como manuscrito até 1968, como estranha Augusto da Costa Dias que neste ano o trouxe a letra de forma ${ }^{43}$ :

Quero cantar de Amor delícias, gozo,

Que as lassas cordas já não sofrem prantos... ${ }^{4}$

43 Queremos relevar o excelente e extenso trabalho introdutório e as notas com que este estudioso de Garrett enriqueceu a edição (Portugália).

44 A. G., O Roubo das Sabinas, Poemas Libertinos, I, reprodução fac-similada do manuscrito existente na Biblioteca Geral da Universidade de Coimbra, espólio de Garrett. Edição crítica, fixação de texto, reprodução e notas de Augusto da Costa Dias, Lisboa, Portugália, 1968, p. 135. 
E depois de desnudar

...ecos gostosos

Do arrulbo do prazer, débeis suspiros, ${ }^{45}$

descreve, mais à frente, os dotes corporais da exposta Sabina e os olhares gulosos do seu fortuito contemplador:

Em torno dos lindos nacarados lábios

Lascivos beijos ávidos revoam.

Em doce agitação pausada, e branda

Os níveos globos túmidos flutuam

Adeja entre eles lúbrico desejo. ${ }^{46}$

Sobe, desce, recua, hesita, anseia

Não ousa... Mas tão próximo à ventura

Ao sacrário de amor, ao foco, ao centro

Do prazer do deleite há-de fugi-lo

Suspira... e entra... e desfalece... e morre. ${ }^{47}$

Nesta espécie de borrão, já ensaiava o jovem fórmulas e cenas que havia de fixar no Retrato, algumas quase decalcadas. Gomes de Amorim referir-se-á à primeira composição, de que transcreve uma parte inicial, como "irmã gémea" da segunda, criticando nela a demasiada nudez e liberdade de ideias e acabando por tentar justificar as duas como resultado de um "estado patológico peculiar às grandes comoções do cérebro: tendências sensualistas" ${ }^{\prime 4}$. Mas o que acontece é que, neste Retrato de Vénus, a realista descrição dos sentimentos e actos dos deuses tornados homens, rompia temerária e até violentamente, com cânones que tinham consagração nos sexto e nono mandamentos da religião que o educara, substituindo a voz da Igreja, chegando ao extremo de tornar a fornicação

\footnotetext{
45 Ib., 143.

46 Ib., 159.

47 Ib., 161.

48 Amorim, op. cit., vol. I, p. 175.
} 
virtude e o adultério acto moral, se ditados por desejo natural que a consciência não reprovasse. Neste contexto, atribuímos significado relevante à interrogação carregada de pedagogia geral e, consideramos nós, de visão prospetiva da sua vida:

Ab! Se o gosto supremo a um deus não peja,

Porquê mesquinhas leis nos vedam bárbaras

Tão suave pecar, doce delito,

Antes virtude, que natura ensina. ${ }^{49}$

Foi preceito adotado, como o mostra a vida do sempre enamorado poeta, e o prova em excesso a paixão derradeira com a Andaluza, a sua Luz, o clímax das suas paixões. Parcelas de Flores sem Fruto, cartas salvas Ignoto Deo e esses cantos pertencentes "todos a uma época de vida íntima" 50 constituirão a memória sentida dessa paixão. No Retrato de Vénus, o céu descera à terra e desvelara-se na pujança sensual dos corpos. Agora eram os corpos, eles próprios, reais, que revelavam a transcendência através de um sentir celestial que chegava ao céu em êxtases sublimes. Pela mediação do corpo, escancarava-se a alma e chamava-se esta a usufruir o que os sentidos não conseguiam abarcar. Ele o revela, concitando de novo olhares de mal querer e juízos reprovadores. Nas cartas, a linguagem é menos censurada, e a sensualidade resvala nas palavras que dizem os momentos vividos. "Oh! como eu vou olhar para ti, como vou ver-te, palpar-te, sentir-te! A ti... eu" 51 ! diz sem pudor em tempo de intervalo passional. Entretanto, as justificações do que socialmente são desvarios, e naturalmente virtudes, recebem a aquiescência e a proteção de Deus, do seu Deus deísta, e permitem-lhe dispensar o céu do além pelo que tem cá, atenuando e confundindo limites entre o paraíso das delícias do amor apaixonado deste mundo e a bem-aventurança do outro, que não sabe medir: "A noite de ontem, minha alma, foi o dia mais belo da minha vida. Oh Deus eterno! Como eu vivi, o que gozei! Se pode haver céu depois disto"? E noutro passo, mantendo o refrão de vivência afim: "Que noite a de ontem, que dia o de hoje! Eu nado em felicidade[...]. Isto não pode acabar,

\footnotetext{
49 A. G., Obras de... op. cit., vol. II, p. 631.

50 Ib., p. 157.

51 A. G., Cartas de Amor..., op. cit., p. 165.
} 
isto é muito celeste de mais para estar sujeito às misérias e variedades das coisas da terra" 52 .

Rosa dá-lhe tudo, ela é a dádiva que a Natureza lhe proporcionou para gozar a felicidade imanente, ela é o seu Deus - "Rosa minha, meu Amor, meu Deus"53 -, e o adultério torna-se destino e estratégia da própria Previdência para regresso ao homem natural, à inocência perdida onde não tem lugar a moralidade que só tem sentido em sociedade corrompida que a gera por necessidade:

Que Deus se compadeça de nós, Amor, já que nos lançou neste paraíso de delícias. [...] Há dois homens em mim, vida desta alma; um é o que vêem todos, o que fez a experiência, a sociedade e o conhecimento de suas misérias e nulidades - o outro é o que tu fizeste, é a criação do teu amor, a tua obra, e este vale muito decerto porque é feito à tua imagem ${ }^{54}$.

Se aqui houvesse Carlos, agora seria outro, pois era regressado à natureza, onde se sentia bem. O homem duplicado deixava de o ser, pois prazer e virtude era uma só coisa num mundo natural. Nesta base, o veredicto da natureza suplanta a situação da família, mesmo a sacramentada: "E Deus o sabe também, R., e nos há-de proteger, e dizer bem que nos perdoa decerto todas as nossas faltas passadas, porque este amor nos purifica e nos restitui à primeira inocência" 55 . E noutro momento: "Tu sabes que tenho fé na Providência e em que ela protege um amor sincero e puro como o nosso, que se elevou a uma paixão sublime, a um sentimento celeste e digno da protecção dos anjos" ${ }^{56}$. É neste diapasão que joga a provocação suprema, convertendo a máscara do engano na vivência da sociedade perversa em instrumento de salvaguarda daquela inocência perdida que a Providência requer como vingança da hipócrita moral social: "joguemos a nossa comédia, que é preciso irmo-nos ensaiando assim" ${ }^{57}$.

\footnotetext{
52 Ib., pp. 103 e 107.

53 Ib., p. 141.

54 Ib., p. 184.

55 Ib., p. 143.

56 Ib., p. 165.

57 Ib., p. 184.
} 
Nas Folhas Caídas, fervilhará a mesma paixão, idênticos referenciais, linguagem par, embora com cuidados poéticos e cautelares de obra que seria pública. Fixemos a memória do vivido em "Aquela Noite" de festa trespassada de amores e desejos, de beijos de bocas ardentes e lascivas, de seios nus e palpitantes, de convites ousados, de conversas despudoradas sobre amores brutos:

Era a noite da loucura,

Da sedução, do prazer,

Que em sua mantilha escura

Costuma tanta ventura,

Tantas glórias esconder.

$[\ldots]$

E daî? - Daí a bistória

Não deixou outra memória

Dessa noite de loucura,

De sedução, de prazer...

Que os segredos da ventura

Não são para se dizer.58

Nelas registará o momento do fatal cruzar de olhos que fez nascer "Este inferno de amar" e fez tornar o gozo, dor ("Gozo e Dor") pelo excesso de um prazer sem fim e pela míngua de vida e alma para usufruir tão excelsa ventura; nelas contará a experiência de amor sem medida em campo aberto, sob os olhares da selvagem natureza:

Ai, na quebra do monte,

Entre uns juncos mal medrados,

Seco o rio, seca a fonte,

Ervas e matos queimados,

Aí nessa bruta serra,

Aí foi um céu na terra.

58 A. G., Obras de..., op. cit., vol. II, pp. 165 e 170. Transcreveram-se apenas os primeiros e últimos versos. 
Inda ali acaba a terra,

Mas já o céu não começa;

Que aquela visão da serra

Sumiu-se na terra espessa,

E deixou nua a bruteza

Dessa agreste natureza. ${ }^{59}$

Enfim, nelas cantará os olhos da amante, que os seus cegaram com chama de queimar... Quanto à linguagem, retoma a da sensualidade que envolve o corpo e que na mocidade, concretamente no Retrato de Vénus, utilizara.

Este naturalismo e sensualismo exacerbados que transpiram das Folhas Caídas voltaram a perturbar Amorim, dividindo-lhe os sentimentos entre a admiração da sensibilidade criadora do poeta e a sua reserva moralista. O nascimento de tais versos de "chama impura" e o serem atravessados por "um palpitar de carnes, um ferver de sangue, uma febre devoradora de gozos", retraía a expressão do seu louvor, proferindo a heresia contra a arte da criação de que preferia que a obra não tivesse sido escrita do que ver-se obrigado a defendê-la. A questão do adultério era, para o autor das Memórias Biográficas de Garrett, exasperante. Mas o arrebatamento pelo seu biografado impôs-lhe indulgência: “... até a pureza do céu é maculada por nuvens negras, e nem sequer o sol, esse mundo luminoso, que espalha em nosso universo o calor e a vida, está isento de manchas..." ${ }^{\circ 0}$. A admiração pelo talento impunha-se ao desgosto do delírio pecaminoso. Seria muito mais adverso e radical o juízo do autor espanhol Romero Ortiz que, em La Literatura Portuguesa en el siglo XIX (Madrid, 1870) lamentava que o poeta do Porto não tivesse queimado tal obra ${ }^{61}$ ! Mas ainda bem que o não fez, pois se queimariam as folhas de uma época única da vida íntima de quem tanto amou e tão admiravelmente escreveu...

\footnotetext{
59 Ib., pp. 195 e 197. São duas estrofes de "Cascais".

60 Amorim, op. cit., vol. III, p. 175.

61 Apud Amorim, ib., pp. 498-499.
} 


\section{Os delitos}

A par de razão, natureza é ideia central e estruturante das luzes. Ela trouxe para a imanência as concepções e interpretações do mundo, do homem e de Deus e foi base de construção da modernidade. Garrett abraçou este caminho e concedeu à ideia de natureza espaço privilegiado, na sua adesão aos projetos de modernidade. Fê-lo no campo da política e dos valores, fazendo radicar na natureza, como os filósofos naturalistas e em particular Rousseau, a liberdade e a igualdade que o guiaram sempre; no da educação, privilegiando o corpo e o método de análise que é o método da natureza, como assevera no tratado Da Educação; no da religião, aderindo aos caminhos da religião natural que também escolheu como verdadeira alternativa à educação religiosa das crianças e jovens; no da moral, dando a este vetor estatuto paralelo ao da física, e deslocando o critério de distinção entre o bem e o mal, de Deus para a voz da consciência individual que a Natureza inspira. Por tudo isto, ele se tornou padrão e referência cimeira do liberalismo em Portugal no que este teve de mais avançado, permanecendo o seu ideário como inspirador incontornável dos caminhos da República. Mas estas são também algumas das razões que fazem sobressair o paradoxo que o vem perseguindo no que respeita às conceções, representações e perspetivações da natureza e da vida das mulheres. Por ironia, havia de ser precisamente no naturalismo, mola de tantos progressos, que ele haveria de sustentar este delito, colhendo argumentos onde sustentara caminhos tão inversos. Também aqui, Rousseau foi o grande esteio, a par da ideologia enciclopedista, tão parcas, um e outra, em avanços nesta área ${ }^{62}$.

Se consultarmos na Encyclopédie de Diderot e d'Alembert a entrada Femme (droit naturel), pode ler-se:

O ser supremo, considerando que não era bom que o homem estivesse só, inspirou a este o desejo de ter uma companheira em sociedade com acordo voluntário. Esta sociedade tem por fim principal a procriação e a conservação dos filhos que nascem até à autonomia destes. E embora marido e mulher tenham os mesmos

62 Para desenvolvimento dos contrastes entre modernidade e tradicionalismo em Garrett, pode consultar-se Fernando Augusto Machado nos escritos indicados na nota 33. 
interesses, é fundamental que só um tenha o governo. Ora, o direito antigo e moderno das nações dá ao macho a autoridade, ficando a mulher sujeita ao marido e tendo de obedecer-lhe. Pode haver excepções... ${ }^{63}$

Na sequência do artigo que contempla outras aceções, encontramos projeções que seguem a toada, nomeadamente na aceção moral que elenca desigualdades várias entre os géneros (força, majestade, coragem, razão, versus graça, beleza, delicadeza, sentimento); na de jurisprudência, em que os distingue através das capacidades de emprego; na de casada, em que consagra que a mulher é obrigada a seguir o homem para onde quer que ele julgue que deve ir.

Por seu lado, Rousseau consagrará e aprofundará no seu Émile este quadro pouco inovador. Como o nosso poeta, também ele amou muito as mulheres e foi objecto de alguns amores delas, mas não ultrapassou a pecha de as considerar diferentes e inferiores em vários aspetos ${ }^{64}$. A teoria que ele segue é simples: homem e mulher são da mesma espécie, mas distinguem-se pela constituição que têm. Ora, dado que este princípio de desigualdade se inscreve na natureza, a sociedade deve respeitá-lo através das diferenças de destino que necessariamente gera, pois que se no estado natural havia atos e diferenciações que não acarretavam consequências pelo tipo de vida que havia, não era o mesmo no estado social. Assim, por exemplo, com a diferença de força física que em situação natural não se repercutia senão no próprio, e que, em situação familiar ou social gera hierarquias, implica sujeições, determina direitos e deveres; com o pudor e o desejo de agradar caraterísticos nas mulheres que, de inclinação, se torna dever na situação conjugal; o mesmo com o ato sexual que se transforma de instinto e busca de prazer, também em dever, na situação referida; com a gestação e criação de filhos que arrasta, na situação social, modos de vida incompatíveis com a vivência livre ou o exercício profissional por parte da mulher; com a divisão de tarefas que se devem compatibilizar com as diferenças físicas, etc. Este é o padrão que Sofia, noiva destinada ao Emílio, tem de aprender e praticar. É no livro V do famoso tratado Emile ou de l'Éducation que ele teoriza esta

${ }^{6}$ Encyclopédie ou Dictionnaire Raisonné..., op. cit., vol. VI. Paris, Chez Briasson et al.., MDCCLVI.

64 Para mais detalhes desta problemática, veja-se o artigo de H. Coulet "Femme", no Dictionnaire de Jéan-Jacques Rousseau (dir. de Raymond Troussou et Fréderic S. Eigeldinger, Paris, Honoré Champion Éd., 1996). 
educação feminina. Aí ditará que é da ordem natural que a mulher obedeça ao homem; que o homem tenha o direito de comandar e a mulher o de governar quem o comanda através do império da doçura, da graça, da complacência, dando ordens com carícias e choros e governando bem a casa, local onde deve exercer mais autoridade. "Mas quando ela", - diz a dada altura - "desconhece a voz do chefe e quer usurpar os seus direitos e comandar ela própria, não resulta disto senão desordem, miséria, escândalo e desonra" ${ }^{65}$. É curioso constatar como o filósofo lê a autonomia feminina, detestando mulheres casadas que se tornassem autoras ou estudassem para serem independentes. Corrupção de costumes, deboche, adultério seriam, no seu entender, consequências frequentes de tais pretensões.

Pois bem, Garrett não se afastou muito destes quadros de referência e colheu, por vezes, situações e até fórmulas destes cânones, incorporando a dualidade contraditória dos que o inspiravam nesta matéria, apesar de tão comprometidos com as luzes e tão avessos à paragem da história. Com efeito, como estes, ele compreendera e anuíra à importância da razão e do progresso para realização do projeto da ilustração; teorizara e praticara militantemente o valor da educação como condição da liberdade dos indivíduos e dos povos; reconhecera que a substituição das abstrações metafísicas e teológicas pela Natureza e a imanência fora a base fundamental para o reconhecimento da razão e a mudança de perspetiva metodológica que permitiu a inauguração de um novo paradigma epistemológico que mudou o mundo; enfrentara os velhos guardadores da moralidade e encontrara na terra o céu através dos deleites das mulheres. Contudo, não foi capaz de conceder a estas papel relevante nestas conquistas, como nem sequer projetou para elas, destas conquistas, alavancas seguras para a sua necessária dignificação. Não o fez, de facto, pelo menos na medida que se impunha e que dele se esperava. Foi parco e até prevaricador. Escusadamente, inconsequentemente, até desatentamente... Na verdade, Garrett era homem muito culto e conhecedor da Europa geográfica e intelectual. O século anterior e até antes consagrara já significativos avanços nesta área da libertação e dignificação da mulher: Fénelon corria mundo através do De l'Éducation des Filles (1687); M. ${ }^{\text {me }}$ Lambert publicara Avis d'une Mère à Sa Fille (1747); M. ${ }^{\text {me }}$ Graffigny escrevera Les

65 Rousseau, Émile ou de l'Éducation..., op. cit., p. 767. 
Lettres Péruviennes (1781); M. ${ }^{\mathrm{me}}$ d'Epinay já militara pelos direitos à educação do seu género nas Conversations d'Emilie (1781); o mesmo com M. ${ }^{\text {me }}$ de Staël, nas Lettres sur le Caractère et les Écrits de J.-J. Rousseau (1788), e outras e outros mais a quem, por sinal, recorreu e até citou no seu tratado Da Educação (1829). Mesmo por cá se chegara bastante mais longe em tempos já idos, com Vernei ou Luís Mousinho de Albuquerque ${ }^{66}$.

Garrett enredou-se na teoria da regeneração da humanidade, de Rousseau, que conhecia muito bem, mas omitiu para as mulheres, como o seu mestre, a última fase do processo. As virtualidades do selvagem, do homem naturalmente bom, deviam manter-se como referência na construção do homem novo. E dado que o regresso à situação anterior já não era possível nem conveniente, o pai da educação moderna criou um sistema educativo próprio a recriar esse homem novo para a sociedade do Contrato, uma sociedade com homens-naturais-de-cidade, uma sociedade evoluída, livre, feliz. Ora, o nosso cidadão portuense também desejou esta sociedade assim, mas fazendo permanecer nela a mulher quase na primeira versão, apenas moldada a esta segunda condição, mas não reconstruída. Assim a pensou, assim a desejou, assim a amou, assim a escreveu.

Apresentamos uma breve mas diferenciada ilustração.

Começamos com um poema que inseriu nas Flores sem Fruto, mas datado de 1823, que vai buscar e traduz da letra de Anacreonte. O título é sugestivo e podia integrar o Livro V do Émile para que Sofia aprendesse a governar quem a comanda:

\section{A Força da Mulher}

Ao touro deu córneas pontas

A própria natureza,

Deu à lebre a ligeireza,

E a dura pata ao corcel.

66 O "Apêndice à Carta 16. ${ }^{\mathrm{a}}$ sobre os estudos das mulheres do Verdadeiro Método de Estudar (1746) e as Ideias sobre o Estabelecimento da Instrução Pública em Portugal (1823), respetivamente, provam a afirmação. 
A voar ensina as aves

A nadar ao peixe mudo;

E deu ao leão sanhudo

O dente destruidor;

Aos homens deu a prudência;

À mulher não pôde dá-la...

Acaso quis deserdá-la,

Ou então com que a dotou?

Por armas e por defesa

Deu-lhe as formas engraçadas

Que o ferro, o fogo, as espadas

Que tudo podem vencer.

Este posicionamento tão naturalista quanto discriminatório do sexo feminino, não é estreante. No célebre O Toucador, Periódico sem Política Dedicado às Senhoras Portuguesas $(1822)^{67}$, com o qual quis elevar o nível da sua iletrada e pouco habituée esposa Luísa Midosi, estabeleceu ele, com o colaborador Luís Francisco Midosi, um plano de matérias em nove lições subordinadas aos seguintes temas: modas, visitas, bailes, jogo, teatro, passeios, banhos, assuntos vários e namoro ${ }^{68}$. Eis as "pertinentes" competências que aperfeiçoariam a natureza e a condição de esposas das leitoras. O perfil das duas vertentes era logo traçado no primeiro parágrafo do periódico:

Sexo amável e encantador, que fazeis as nossas delícias, aprimorais os nossos prazeres, adoçais nossas amarguras, e sois a essência da vida, o afago da existência; [...] nascestes para encantar-nos; nascemos nós para servir-vos.

E um pouco à frente traça o destino de vida:

67 Lisboa, Veja, 1993.

68 Ib., pp. 25-26. 
Protecção na infância, encanto na mocidade, companhia na idade madura, amparo na velhice; desde o berço até à sepultura, só vosso benigno influxo nos ameiga a existência, nos aformoseia a vida, e espalha mimosas flores em seu difícil caminho ${ }^{69}$.

Eram os homens quem falava...

Os testemunhos deste retrógrado ideário são muitos. É muito curiosa a apresentação que dele faz assunto no inacabado romance Helena. Implacavelmente tradicionalista, veicula-o através de duas personagens femininas: Isabel e a mãe. Parece transcrever Rousseau, ao afirmar através da primeira que a mulher literata - Rousseau falava das mulheres que escrevem, as autoras - era "a coisa mais ridícula e abortiva do mundo"70; e se a filha diz, a mãe redobra, pondo-lhe na boca o princípio, tornado conselho à filha, de que a inocência, que identifica com ignorância, é virtude insubstituível na mulher que quanto mais sabe mais erra $^{71}$. Como estava perto o exemplo que M. le Chevalier de Jaucourt dava, no artigo já falado que fez para a Encyclopédie - "Femme (anthropologie)" - para mostrar como a história anterior sempre inferiorizara as mulheres. Recorria, na circunstância, ao dito, tornado aforismo, do poeta Publius Syrus: Mulier cum sola cogitat, male cogitat (a mulher quando pensa só, pensa mal). Nesta senda, relembramos, sem mais análise, a tão conhecida imagem que o nosso romancista traça de Joaninha, em contraposição com a de Carlos, nas Viagens. Apontamos, tão só, a preferência por uma inocência e beleza naturais, contra a máscara das "boquinhas gravezinhas e espremidinhas" que a doutorice molda. É, aliás, esta doutorice que invoca no conselho que dará, em carta de 1 de fevereiro do ano da sua morte, 1854, à sua querida filha Maria Adelaide, quando a relega relativamente à preocupação que deve ter com o ser boa e temente a Deus. Finalmente, pela especificidade que contém, referimos a peça do elogio fúnebre que fez à duquesa de Palmela. É um hino à vida da mulher como matrona romana, enaltecendo a alma de quem havia servido tão subidamente, e quase

\footnotetext{
69 Ib., p. 23.

70 A. G., Obras de..., op. cit., vol. I, p. 443.

$71 \quad$ Ib., p. 437.
} 
em exclusão, os deveres tão próprios da mulher enquanto filha, enquanto mãe e enquanto esposa.

É, todavia, no tratado Da Educação que o seu pensar nesta matéria mais se desenvolve e sistematiza. É assunto que já tivemos oportunidade de analisar com algum pormenor noutros escritos, por isso recordaremos só alguns tópicos sintomáticos da perspetiva do autor.

Começamos por dizer que, mais uma vez, ele segue de muito perto, na obra, o inspirador central do tratado: o cidadão de Genebra. Com ele teorizará pressupostos e elencará consequências. Sob o lema de que nada poderá contradizer o que a natureza manda, afirmará a igualdade em espécie dos dois sexos, mas relevará desigualdades de género que conduzirão a destinos diferenciados. A carta nona é um texto carregado de ambiguidades e de tradicionalismo sobre a conceção e o quadro de vida da mulher. Lá justificará como a força que Deus pôs no braço do homem pode ser contrabalançada pela força dos lábios e dos olhos da mulher; como esta não pode, por esta e outras diferenças, exercer serviços iguais aos do homem; como a mulher que deixa de ser mãe, função para que a natureza a talhou, para ser erudita, autora ou estadista, é tudo menos mulher ${ }^{72}$. Estas mesmas convicções o levarão a considerar o sexo como um dos critérios diferenciadores da organização educacional que propõe para o segmento da educação intelectual. O princípio a que aplica tal critério faz entender o alcance: "Todos carecemos de educação intelectual, mas nem todos igualmente"73.

Para quem defendeu princípios tão avançados para o sistema educativo português, quer no corpo geral do tratado Da Educação, quer no avançadíssimo Plano da Reforma Geral dos Estudos (1834), feito para aplicar ao país depois da vitória dos liberais na guerra civil, não deixa de ser surpreendente este gravoso conjunto de delitos. Mas, no melhor pano cai a nódoa, como sói dizer-se, e não deixa de ser pano! Garrett também não deixa de ser o mais lídimo e avançado representante das luzes e do liberalismo em Portugal, apesar deste escusado delito contra o género feminino que lhe proporcionou tão grandes e intensos deleites no amor e na escrita e a nós tão grandes e intensos deleites de leitura.

72 A. G., Da Educação, Edição Crítica das Obras de... coord. Ofélia Paiva Monteiro, editor crítico Fernando Augusto Machado, Lisboa, Imprensa Nacional-Casa da Moeda, 2009, p. 191-193.

73 Ib., p. 116. 